\title{
Enteral feeding with elemental and nonelemental diets in Crohn's disease
}

\author{
DANIEL RIGAUD, MD
}

D RIGAUD. Enteral feeding with elemental and nonelemental diets in Crohn's disease. Can J Gastroenterol 1993;7(2):200-207. The role of nutritional therapy in Crohn's disease is indisputable. The management of patients with Crohn's disease is incomplete without an evaluation and, if necessary, a specific therapy of malnutrition. Besides medical therapy, enteral support should be considered as 'primary therapy' in the acute phases of the disease (namely in malnourished patients), because elemental and nonelemental diets achieve clinical remission in 66 to $88 \%$ of cases. In controlled trials, elemental diets were unable to show better results than nonelemental (semi-elemental and polymeric) diets. However, elemental diets may allow faster clinical improvement than other formula diets. Previous controlled studies have indicated that the effect of enteral diets is not symptomatic because of improvements in inflammatory status and in active bowel lesions. Basic research on the mechanisms of action of enteral feeding is awaited.

Key Words: Crohn's disease, Elemental diet, Nutritional therapy

\section{Alimentation entérique à l'aide de formules élémentaires et non élémentaires dans la maladie de Crohn}

RÉSUMÉ: Le rôle du traitement nutritionnel dans la maladie de Crohn est indiscutable. Le traitement des patients atteints de la maladie de Crohn n'est pas complet sans une évaluation et au besoin, un traitement spécifique de la malnutrition. En plus du traitement médical, un soutien entérique doit être envisagé en premier lieu lors des phases aiguës de la maladie, notamment chez les patients dénutris, parce que les régimes élémentaires et non élémentaires procurent une rémission clinique dans $66 \%$ à $88 \%$ des cas. Lors d'essais contrôlés, les régimes élémentaires n'ont pas donné de meilleurs résultats que les régimes non élémentaires (semi-élémentaires et polymériques). Cependant, les régimes élémentaires pourraient donner lieu à une amélioration clinique plus rapide que d'autres formules diététiques. Des études contrôlées ont précédemment indiqué que l'effet des régimes entériques n'est pas uniquement symptomatique, étant donné les améliorations au niveau du statut inflammatoire et des lésions intestinales actives. La recherche fondamentale sur les mécanismes d'action de l'alimentation entérique est tout à fait indiquée.

Service d'Hepato-Gastroenterologie, CHU Bichat-Claude Bernard, Paris, France

Correspondence and reprints: Dr Daniel Rigaud, Service d'Hepato-Gastroenterologie, CHU Bichat-Claude Bernard, 46 rue Henri Huchard, F 75877 Paris, Cedex 18.

Telephone 33.1.40.25.72.01. Fax 33.1.40.25.05.93
ROHN'S DISEASE IS AN INFLAM.
matory disease which commonly has a course characterized by phases of flare-up of variable duration and severity. Weight loss and malnutrition are prominent features in the course of Crohn's disease, namely during acute attacks (1-3).

The factors initiating the disease clearly are multiple, including genetic predisposition, environmental promoters (including foodstuffs) and host gut and systemic immune responses. The factors related to flare-up are unknown. No one is sure if they are the same as those that initiate the disease.

Among the relapse-promoting factors, alimentary agents and nutritional status have been suspected for more than three decades as possibly initiating or perpetuating Crohn's disease (4. 6). Crohn's disease is virtually absent in countries where dietary fibres constitute a major source of carbohydrates and refined carbohydrates are lacking. These epidemiological intercountry data fit well with the case-control study of Thornton et al (4), who found that Crohn's disease patients ingested more refined carbohydrates and less dietary fibres before their illness than healthy controls. Similar results were obtained by Martini et al (5) and Mayberry et al (6). Other authors have suspected histamine-releasing or -containing foods. If the effects of a particular foodstuff in initiating or perpetuating Crohn's dis- 
Enteral feeding in Crohn's disease

ease now appears unlikely, there is no doubt that the diet (at least the 'occidental' diet) may induce relapse or recurrence. (One should note that the present use of 'diet' includes all the components of dietary habits, including meals, cooking and foods, and all their direct and indirect effects). Arguments for a role of diet are clearly speculative but plausible, and include (a) surgical procedures inducing exclusion of a bowel segment, such as ileostomy or colostomy, that commonly were followed by ulceration healing in the diseased-excluded segment (7) and (b) exclusion diets that have been effective in maintaining remission in Crohn's disease (8).

This putative effect of diet has allowed several authors $(9,10)$ to formulate a 'bowel rest' concept. Accordingly, the efficacy of total parenteral nutrition (TPN) for inducing remission (60 to $90 \%$ ) was tested, with TPN suggested to be of interest in acute Crohn's disease, and in severe, steroid-dependent or -resistant forms $(1,3,11,12)$. Although these studies did not include a randomized placebo-controlled group, it is reasonable to assume that TPN probably is effective. Whether TPN is as effective as steroid for first choice therapy of flare-ups remains to be determined $(13,14)$; the author believes further studies regarding the disadvantages (namely cost) and side effects of TPN are unnecessary, except in severely malnourished patients.

The limits of TPN led to the first works on elemental diets in Crohn's disease. Voitk and colleagues (9) showed that some patients, prepared for surgery by an elemental diet, improved both inflammatory and nutritional status. Other workers (15) noted that clinical improvement was associated with a decrease in radiologic active lesions in Crohn's disease ileitis. These preliminary encouraging results were further extended to patients with nonsurgical active diseases (10) and to pediatric patients (16-18).

From 1984-87, four clinical trials suggesting that elemental diets were as effective as TPN (19) or steroids (20. 22) were published. Overall, the remission rate on elemental diets was 78 to

TABLE 1

\section{Controlled trials comparing elemental diets with total parenteral nutrition or steroids in active Crohn's disease}

\begin{tabular}{|c|c|c|c|c|c|}
\hline $\begin{array}{l}\text { Trial } \\
\text { (reference) }\end{array}$ & $\begin{array}{l}\text { Number of } \\
\text { patients (n) }\end{array}$ & $\begin{array}{l}\text { Treatment } \\
\text { duration }\end{array}$ & $\begin{array}{l}\text { Prednisone } \\
\text { (mg/kg/day) }\end{array}$ & $\begin{array}{l}\text { Remission } \\
\text { rate (\%) }\end{array}$ & Remarks \\
\hline \multirow{2}{*}{$\begin{array}{l}\text { Alun Jones } \\
\text { (19) }\end{array}$} & TPN (19) & 2 weeks & - & 87 & \multirow[t]{2}{*}{ No other therapy } \\
\hline & $\mathrm{ED}(17)$ & 2 weeks & - & 86 & \\
\hline \multirow{2}{*}{$\begin{array}{l}\text { Savery- } \\
\text { muttu } \\
\text { et al (21) }\end{array}$} & $\operatorname{TPN}(16)$ & 1.4 weeks & 0.5 & 100 & \multirow{2}{*}{$\begin{array}{l}\text { Nonabsorbable } \\
\text { antibiotics } \\
\text { were used in } \\
\text { the ED group }\end{array}$} \\
\hline & $\mathrm{ED}(16)$ & 1.4 weeks & - & 93 & \\
\hline \multirow{2}{*}{$\begin{array}{l}\text { O'Morain } \\
\text { et al }(20)\end{array}$} & $\operatorname{TPN}(10)$ & 4 weeks & 0.75 & 80 & \multirow{2}{*}{$\begin{array}{l}22 \% \text { relapse rate } \\
\text { at six months in } \\
\text { the ED group }\end{array}$} \\
\hline & ED (11) & 4 weeks & - & 82 & \\
\hline \multirow{2}{*}{$\begin{array}{l}\text { Seidman } \\
\text { et al (22) }\end{array}$} & $\operatorname{TPN}(n=9)$ & 3 weeks & 1.0 & 67 & \multirow[t]{2}{*}{ Pediatric patients } \\
\hline & $\operatorname{ED}(n=9)$ & 3 weeks & - & 78 & \\
\hline
\end{tabular}

None of the differences in clinical remission was significant; ED Elemental diet; Pred Prednisone; TPN Total parenteral nutrition

\section{TABLE 2}

Characteristics of elemental, semi-elemental and polymeric diets

\begin{tabular}{|c|c|c|c|}
\hline Characteristic & Elemental diets & Semi-elemental diets & Polymetic diets \\
\hline Nitrogen source & Amino acids & $\begin{array}{l}\text { Small oligopeptides } \\
\text { (200 to } 5000 \text { Da) }\end{array}$ & $\begin{array}{l}\text { Oligopeptides } \\
\text { (>2000 Da) }\end{array}$ \\
\hline Fats & Safflower, $\leq 10 \%$ TEC & $\begin{array}{l}\text { Safflower ( } 50 \% \text { fats), } \\
\text { MCT ( } 50 \% \text { fats), total } \\
\text { fats = TEC } 10 \text { to } 30 \%\end{array}$ & $\begin{array}{c}\text { Soy or corn, } \pm \text { MCT } \\
\text { (10 to } 30 \% \text { fats), total } \\
\text { fats }=\text { TEC } 30 \%\end{array}$ \\
\hline Osmolality & $\begin{array}{l}\text { High }(>450 \\
\text { mOsm } / \mathrm{kg})\end{array}$ & $\begin{array}{c}\text { Intermediate ( } 300 \text { to } \\
400 \mathrm{mOsm} / \mathrm{kg})\end{array}$ & Low $(<300 \mathrm{mOsm} / \mathrm{kg})$ \\
\hline Sodium content & Virtually absent & Low & Low \\
\hline
\end{tabular}

MCT Medium chain triglycerides; TEC Total energy content; Da Dalton

93\% (Table 1), which was undoubtedly higher than the higher remission rate obtained with placebo (30 to $50 \%$ ) in controlled trials carried out to assess the efficacy of steroid or 5-ASA in the treatment of active Crohn's disease. This remission rate associated with elemental diets compared positively with those obtained with 5-ASA (ie, 57 to $94 \%$ ) or with immunosuppressives (for which efficacy has been demonstrated in approximately $72 \%$ of patients).

The next step in the use of nutritional support in acute Crohn's disease was to look for efficacy of nonelemental diets, ie, semi-elemental and polymeric diets. The common characteristics of these three types of defined formula diets are seen in Table 2. The major differences are related to nitrogen source, fat content and osmolality. The nitrogen source in elemental diets was free amino acids, which explains the higher osmolality of these types of diets. Furthermore, sodium is virtually ab- sent, while it is well-known that amino acid absorption depends on sodium content of the mixture (greater than 80 $\mathrm{mmol} / \mathrm{L}$ sodium ions are needed). Elemental diets contain only a very small proportion of total energy content as fat (less than 2\%) within an 'essential fatty acid-deficiency distance'. Compared with elemental diets, semi-elemental and polymeric diets have different sources of the hydrolyzed protein (meat, lactalbumin or casein) and of lipids (thus, proportions of saturated and unsaturated fatty acids, and of long and medium chain triglycerides differ).

The 'bowel rest' concept was further questioned by the study of Greenberg et al (14); 51 patients with active Crohn's disease unresponsive to medical management received TPN $(n=17)$, partial parenteral nutrition with oral foods $(n=15)$, or a polymeric diet $(n=19)$. Clinical remission occurred in 12 TPN patients $(71 \%)$, in nine receiving partial parenteral nutrition $(60 \%)$, and in 
TABLE 3

Characteristics of 30 Crohn's disease patients presented in reference 30

\begin{tabular}{lcc}
\hline & $\begin{array}{c}\text { Elemental enteral diet } \\
(n=15)\end{array}$ & $\begin{array}{c}\text { Polymeric formula diet } \\
(n=15)\end{array}$ \\
\hline Age (years) & $33 \pm 10$ & $37 \pm 11$ \\
Colon only & 10 & 10 \\
Steroid dependence & 5 & 4 \\
Body weight (\%lBW) & $84 \pm 3$ & $86 \pm 10$ \\
CDAl & $275 \pm 79$ & $239 \pm 67$ \\
\hline
\end{tabular}

Same sex ratio, steroid cumulative dose, disease duration and previous complications in the two groups: CDAl Crohn's disease activity index, IBW Ideal body weight

\section{TABLE 4}

Enteral support: Vivonex HN (elemental enteral diet), or Realmentyl or Nutrison (polymeric formula diet)

\begin{tabular}{lcc}
\hline & $\begin{array}{c}\text { Elemental enteral diet } \\
(n=15)\end{array}$ & $\begin{array}{c}\text { Polymeric formula diet } \\
(n=15)\end{array}$ \\
\hline Duration (days) & $32 \pm 4$ & $36 \pm 7$ \\
Energy (\% EREE) & $154 \pm 19$ & $154 \pm 16$ \\
Energy (kcal/day) & $2286 \pm 227$ & $2311 \pm 304$ \\
Nitrogen (mg/kg/day) & $339 \pm 49$ & $310 \pm 9$ \\
\hline
\end{tabular}

$1 \mathrm{kcal} / \mathrm{min}=16$ to $18 \%$ protein: EREE Estimated resting energy expenditure

TABLE 5

Alpha-1 antitrypsin clearance on enteral support

\begin{tabular}{lcc}
\hline & $\begin{array}{c}\text { Elemental } \\
\text { enteral diet } \\
(n=12)\end{array}$ & $\begin{array}{c}\text { Polymeric } \\
\text { formula diet } \\
(n=12)\end{array}$ \\
\hline Initial & $104 \pm 65 \mathrm{~mL} /$ day & $50 \pm 26 \mathrm{~mL} /$ day \\
Final & $56 \pm 79 \mathrm{~mL} /$ day $^{*}$ & $31 \pm 25 \mathrm{~mL} /$ day $^{\star}$ \\
\hline
\end{tabular}

"P<0.01 versus initial value

11 on a polymeric diet $(58 \%)$. These remission rates were not statistically different, but concomitant steroid treatment makes it difficult to relate the observed improvement to diet alone. Coyle and Sladen (23) also showed a $66 \%$ remission rate with a whole protein liquid diet in patients with mildly active uncomplicated Crohn's disease (patients were on a concomitant steroid treatment).

In children, Kerner et al (24) determined the effects of intermittent semielemental diet (Peptamen, Kabi Pharmacia, Sweden) on growth and disease activity in six Crohn's disease patients with malnutrition. Compared with their previous one-year status, patients had greater height and weight velocities, greater serum albumin and somatomedin C levels, and received lower steroid cumulative dose (the activity index was a little higher during the year of intermittent polymeric diet).

Royall et al (25) compared the efficacy of elemental and semi-elemental diets in 40 patients with uncomplicated active Crohn's disease in a randomized double blind study. Clinical remission occurred in 16 of 19 patients on elemental diets $(84 \%)$ and in 16 of 21 patients on semi-elemental diets (75\%). The two groups had similar nutritional and nitrogen store gains. Engelman and workers (26) also studied the efficacy of a semi-elemental diet in seven outpatients with active ileal Crohn's disease; all patients tolerated the diet, taken by mouth, and all showed a clinical remission at the end of the two-week treatment period.

Four studies comparing polymeric and elemental diets have been published. Park et al (27) and Raouf et al (28) found similar remission rates in patients receiving polymeric diets and in those on an elemental diet. Conversely, Graffer and colleagues (29), compared the clinical remission rates after 10 days of elemental or polymeric diets, and showed elemental regimen to be more effective, with a $75 \%$ clinical response versus a $36 \%$ response on polymeric diet. This study suggests that an elemental diet may allow earlier clinical improvement.
The author's previous study (30) al. lowed extensive comparisons between elemental and polymeric diets. Thirty patients with active Crohn's disease, randomly assigned one of the two diets, participated in the study, which showed that they had very similar clinical characteristics (Table 3). Among these 30 patients, 20 had oral colonic disease. Furthermore, eight patients in each group were free from steroid treatment at inclusion, because the criteria for inclusion were a Best Crohn's disease activity index greater than 150 and an indication for nutritional support. No patient had extensive small bowel disease, fulminant colitis or suspicion of abdominal sepsis.

Diets, administered by nasogastric tubes over at least a 28-day period, consisted of Vivonex (Norwich Eaton, Surrey, UK) (elemental diet) and Real. mentyl (Sopharga, Puteaux, France) or Nutrison (Nutricia, Rueil, France) (polymeric diets). Nitrogen $(320 \pm 15$ $\mathrm{mg} / \mathrm{kg} / \mathrm{day}$ ) and energy inputs were similar (Table 4), the latter consisting of 1.5 times the resting energy expenditure estimated from the Harris and Benedict formula. Importantly, the aminograms and lipid content of these elemental and polymeric diets were not similar. Efficacy criteria were based on the Crohn's disease activity index (CDAI), hematological markers of inflammation and malnutrition, and (in 24 patients) alpha-1 antitrypsin clearance and colonoscopy.

Decrease in disease activity was demonstrated in both types of nutritional support by decreases in CDAl, fecal output, prednisone dose, biological inflammatory markers, alpha-1 antitrypsine clearance and endoscopic stage. The elemental diet group showed a clinical remission rate (CDAI less than 150 ) of $60 \%$ after two weeks and of $66 \%$ after four weeks, (this was $40 \%$ [two weeks] and 73\% [four weeks] in the polymeric diet group). The greater efficacy of elemental diet at day 14 failed to reach statistical significance $(\mathrm{P}=0.073)$.

Fecal weight decreased similarly in both groups, from a mean value (whatever the diet) of $396 \mathrm{~g} /$ day (before enteral support) to 232 and $202 \mathrm{~g} /$ day at 


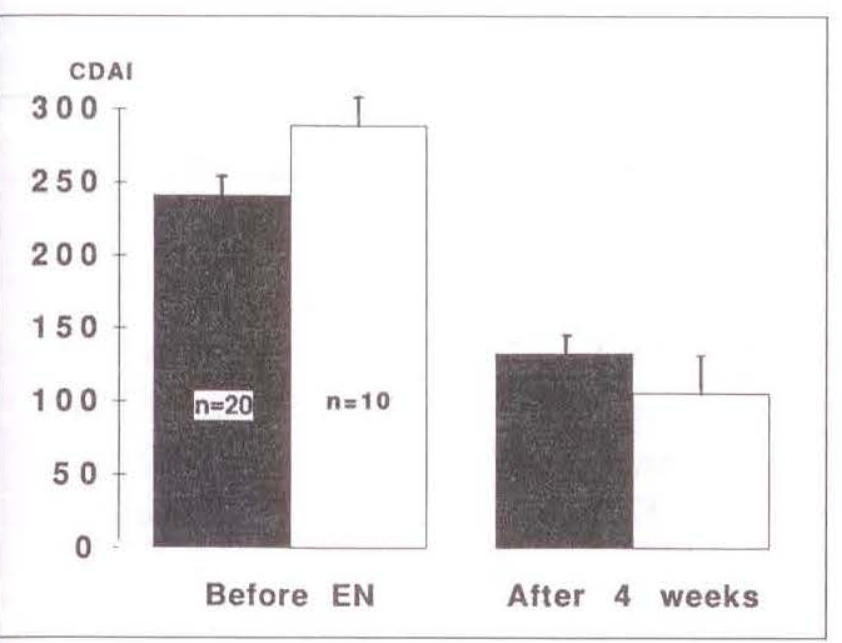

Figure 1) Mean improvement of Crohn's disease activity index (CDAI) on enteral nutrition (EN) (elemental and polymeric diets) in the 20 patients in whom enteral support was decided for severe malnutrition (weight loss at least 15\% and serum albumin of $35 \mathrm{~g} / \mathrm{L}$ or less; (black bars) and in those 10 in whom it was decided for steroid failure (hollow bars). Data are expressed as mean \pm SEM

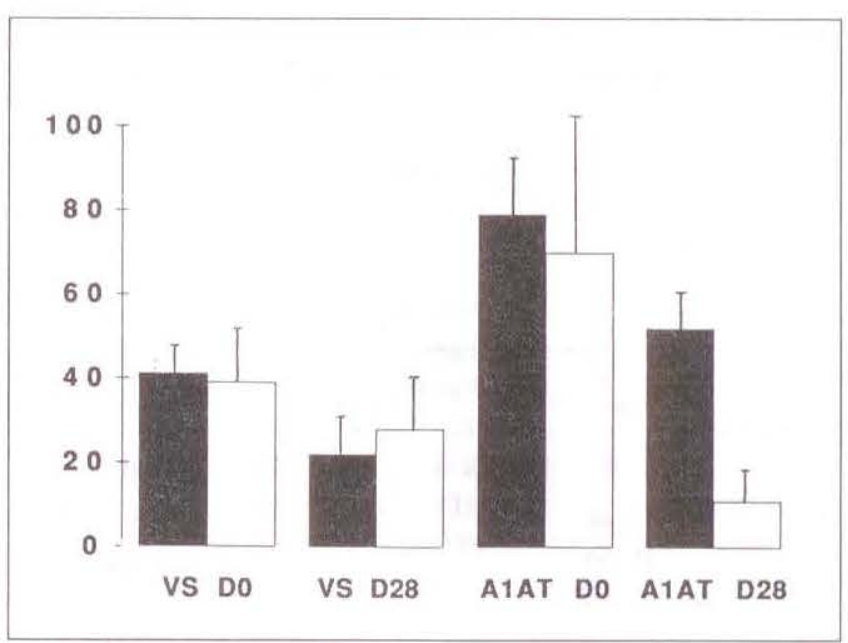

Figure 2) Mean improvement in alpha-1 antitrypsin clearance ( $\mathrm{mL} /$ day) and in sedimentation rate $(\mathrm{mm})$ on enteral nutrition (elemental and polymeric diets) in the 20 patients in whom enteral support was decided for severe malnutrition (weight loss at least $15 \%$ and serum albumin of $35 \mathrm{~g} / \mathrm{L}$ or less; (black bars) and in those 10 in whom it was decided for steroid failure (hollow bars). Data are expressed as meantSEM. DO Day 0; VS Sedimentation rate; D28 Day 28; AlAT Alpha and antitrypsin clearance days 14 and 28, respectively. Approximately one-half of the patients had normal CDAI and fecal weight after 14 days of nutritional support.

As shown in Table 5, alpha-1 antitrypsin clearance also showed a significant and similar improvement in both groups after four weeks of nutritional support; however, it also remained abnormal in nine of the 24 patients in whom it was performed (37\%). A significant fall in inflammatory marker levels (sedimentation rate, alpha-2 globulins) and significant improvements in body weight, triceps skinfold, creatinine height index and serum albumin level were also noted. Disappearance of all ulcerations (except two cases who had a few erosions in one colonic segment) occurred in three (elemental diet) and two (polymeric diet) patients. Indisputable or great endoscopic improvement was observed in 12 more patients. No change or worsening of endoscopic active lesions (ulcerations) was noted in seven of the 24 patients who had undergone colonoscopy $(29 \%)$. The difference between elemental and polymeric diet was not significant for any of the above criteria.

At the end of nutritional support, 23 patients were in clinical remission. During the following 12 months, an obvious clinical relapse or a complication occurred in 14 patients (61\%), six in the elemental group and eight in the polymeric one (this difference was not significant).

The results could be analyzed according to the disease location and to nutritional support (steroid dependance or resistance on one hand, severe malnutrition on the other hand). CDAI, stool weight, sedimentation rate and alpha- 1 antitrypsin clearance decreased in patients in whom enteral support was decided for flare-up and malnutrition, and in those patients in whom steroid therapy failed to induce clinical remission (Figures 1,2). No difference could be evidenced between these two groups.

Another study (personal data) by the author had a very similar design, but compared TPN with enteral support. Nine patients received TPN and 16 patients received elemental $(n=8)$ or polymeric $(n=8)$ diets.

Patients were matched for age, and for duration and location of disease. TPN was administered by a central venous indwelling catheter and enteral nutrition by a nasogastric feeding tube for a mean of 33 to 36 days. Energy input accounted for 1.5 times the estimated resting energy expenditure (after correction for absorption coefficient rates).

All patients but one gained weight and had significant increases in triceps skinfold, serum albumin and transthyretin (thyroxin-binding prealbumin). There was no difference among the three groups for all these gains.

After four weeks clinical remission was achieved in six of nine patients on TPN, five of eight patients on the elemental diet, and six of eight patients on the polymeric diet (not significant). The decrease in CDAI however, was greater for the TPN group than for patients on enteral support. Similarly alpha-1 antitrypsin clearance showed a significant fall in the three groups, but reached a mean nominal value only in the TPN group.

In summary, in the management of flare-ups, enteral support - either by elemental or nonelemental diets - is effective as sole therapy or when steroids fail. In the author's experience, the enteral formula may be of less benefit than TPN, which relieves symptoms more rapidly than enteral support, but follow-up after a four to six week TPN treatment showed that remissions usually lasted less than three to six months in those patients in whom TPN was indicated for failure of 
TABLE 6

Studies on enteral support in active Crohn's disease without fistual

\begin{tabular}{|c|c|c|c|c|c|}
\hline Study (reference) & Treatment & $\begin{array}{l}\text { Number of } \\
\text { patients }\end{array}$ & $\begin{array}{l}\text { Duration } \\
\text { (weeks) }\end{array}$ & Remission rate & $\begin{array}{c}\text { Relapse at one year } \\
\text { (\% patients) }\end{array}$ \\
\hline Bjarnason (35) & ED & 9 & 4 to 5 & $\begin{array}{c}8 \text { (of 9) improved clinically and } \\
\text { biologically: indium-111 leukocyte } \\
\text { (???) }\end{array}$ & ND \\
\hline \multirow[t]{2}{*}{ De Leon (36) } & PFD & 15 & 4 & $80 \%$ & $42 \%$ \\
\hline & $\begin{array}{l}\text { Steroids (1 } \\
\mathrm{mg} / \mathrm{kg} / \text { day) }\end{array}$ & 17 & 4 & $88 \%$ & $67 \%$ \\
\hline Royall (25) & SED & 21 & 3 & $84 \%$ & ND \\
\hline \multirow[t]{2}{*}{ Middleton (37) } & $E D$ & 14 & 2 & $78 \%$ & ND \\
\hline & PFD & 15 & 2 & $73 \%$ & ND \\
\hline \multirow[t]{2}{*}{ Ito (38) } & ED & 8 & 4 to 8 & Normal permeability: $100 \%$ & ND \\
\hline & SED & 5 & 4 to 8 & Normal permeability: $40 \%$ & ND \\
\hline Gorard (39) & ED & 21 & 4 & $71 \%(N S)$ & $91 \%$ \\
\hline Rigaud (30) & PFD & 15 & 4 & $73 \%$ & $56 \%$ \\
\hline \multirow[t]{2}{*}{ Giaffer (29) } & ED & 16 & 1.4 & $75 \%$ & ND \\
\hline & PFD & 14 & 1.4 & $36 \%$ & ND \\
\hline \multirow[t]{2}{*}{ Raouf (28) } & ED & 13 & 3 & $69 \%$ & ND \\
\hline & PFD & 11 & 3 & $73 \%$ & ND \\
\hline
\end{tabular}

Except for Giaffer's study, no difference in rate of clinical remission was noted between groups. "P<0.03 versus polymeric formual diet (PFD), decrease in inflammatory markers significant only in those pateints entering remission; **including improvement in biological inflammatory markers: ED Elementa diet: ND Not done; NS Not significant: SED Semi-elemental diet

conventional medical therapy. Considering the disadvantage of TPN (compared with enteral support), tube feeding must be regarded as the first choice in Crohn's disease. It seems reasonable to assume that semielemental or polymeric diets have similar efficacy to elemental diets. Four to five weeks of treatment seems to achieve acceptable rates of both clinical and endoscopic remissions. The price of the diet should be considered when choosing between elemental and nonelemental diets (for similar efficacy). If no clear clinical improvement is seen after 10 days of enteral feeding, another treatment (eg, TPN) must be decided.

However, several questions remain. For example, is it subgroups of patients in whom enteral support is particularly efficient or, on the contrary, commonly failed? Little is known on this front; there has been no prospective study of enteral support in patients having fistula and no prospective randomized study comparing the results of enteral diet in patients having colonic Crohn's disease with those with ileal disease; but, Teahon and workers (31), reviewing their experience with elemental diets in 113 patients with Crohn's disease, showed that the site of the disease did not appreciably affect the chance of obtaining remission; failure was noted in two of 15 patients (13\%) having colonic disease, nine of $56(16 \%)$ having ileocolonic disease and three of $25(12 \%)$ having terminal ileum lesions.

It is unknown whether enteral support is equally efficient in steroid failure and primary treatment. No difference was shown in our two studies, but it is clear that enteral support could not substitute for steroid in every case. For short term steroid treatment, compliance is good and side effects uncommon, while the nasogastric tube is not always well-tolerated and enteral diet infusion is not as easy to perform in ambulatory patients. Furthermore, Lochs et al (32) showed a 79\% remission rate on medical treatment (methylprednisolone plus sulphasalazine) compared with $53 \%$ on a semi-elemental diet $(\mathrm{P}<0.01)$.

These arguments suggest that enteral support should be indicated only in malnourished patients in whom nutritional support is desirable because of the increase in protein catabolism induced by high doses of steroids.

Another remaining question concerns the choice of enteral nutrition, elemental versus nonelemental diets, according to the site of Crohn's disease. Unfortunately, there is very little information on this field. It is possible, but unproven, that in diffuse small bowel diseases, elemental diets are more efficient than polymeric diets to achieve clinical remission and nutritional replenishment. Andersson et al (33) showed that elemental diets offered no nutritional advantages, compared with polymeric diets, in enteral feeding of patients with minor or major small bowel resections. However, Ziegler and co-workers (34) suggested that after ab. dominal surgery, a small peptide-containing diet (semi-elemental diet) is more effective than an equivalent diet containing whole proteins (polymeric diet) in restoring protein status in intensive care unit patients. One has to consider the osmolarity of the mixtures 


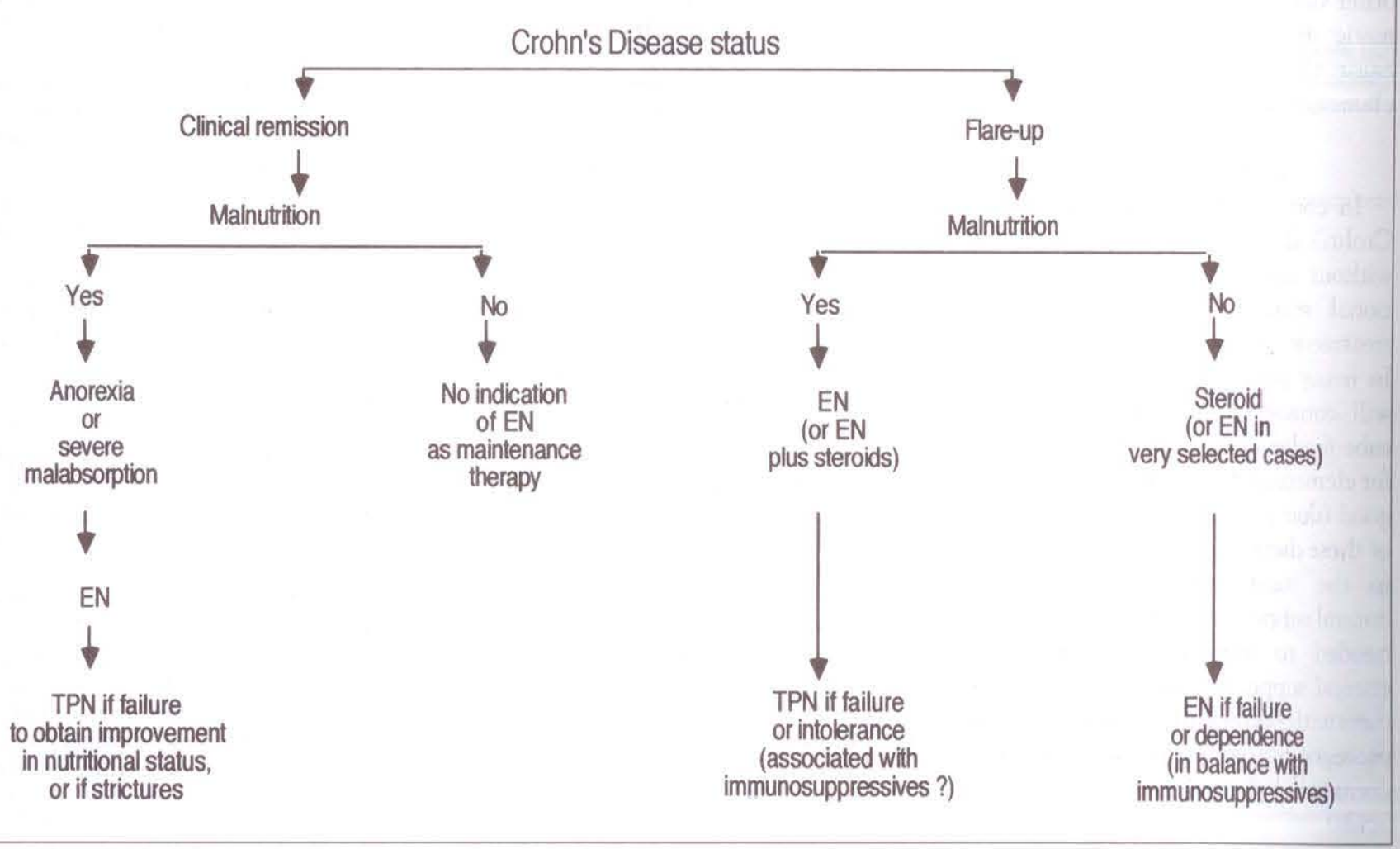

Figure 3) Decision scale for nutritional support in Crohn's disease. EN Enteral nutrition; TPN Total parenteral nutrition

and the sodium content of the diets; lower amino acid absorption is expected with a mixture having a sodium content of less than 70 to $80 \mathrm{mmol} / \mathrm{L}$.

Concerning their efficacy as 'primary' anti-inflammatory therapy, elemental and nonelemental diets seem to bring about similar improvement (approximately 66 to $88 \%$ of patients) after three to four weeks (Table 6).

The question of recurrence of the disease after three to five weeks of nutritional support remains a subject of considerable debate. It appears that enteral support, as TPN, is unable to induce a remission of longer duration than that of classical medical therapy, including steroid. To the contrary, some authors have shown that remission could be less reliable and less longlasting, with a recurrence rate as high as $70 \%$. Parenteral or enteral supports in previous studies (and in practice) have probably concerned those patients having more severe disease and/or more altered nutritional status. It is probable (but unproven) that macroscopic lesions of these Crohn's disease patients are more severe than those of patients who dramatically responded to steroid therapy. Thus, one could expect earlier relapse of the disease in more severe cases. This hypothesis should be tested in prospective studies.

\section{INDICATIONS FOR NUTRITIONAL SUPPORT IN CROHN'S DISEASE}

The methods available to treat malnutrition in Crohn's disease include nutritional supplements (oral preparations), enteral feeding using a nasogastric tube and parenteral nutrition. Today it seems reasonable to treat by enteral feeding or a fortiori parenteral nutrition only those patients having substantial malnutrition (Figure 3).

In malnourished patients in a remission phase of their disease, many authors $(1-17,18)$ have demonstrated that nasogastric infusions improve the nutritional status and allow linear growth rate in pediatric patients. Enteral support is needed in cases of severe malabsorption (for example, related to the short bowel syndrome) and anorexia, a major determinant of weight loss in Crohn's disease. In patients having multiple small bowel strictures or fistula, TPN is preferable, achieving closure of fistula in 20 to $90 \%$ of cases. However, information about the risk of recurrence is necessary. At least TPN is able to provide nutritional support preoperatively and to improve nutritional status of the malnourished patients before surgery. Since the relapse rate after enteral or parenteral support appears to be high, there is no indication for nutritional support as maintenance treatment.

In acute Crohn's disease, patients suffering from malnutrition should be the sole patients to benefit from enteral support; in patients without malnutrition, steroids or other chemical therapy is preferable because of a better compliance and feasibility, and in malnourished patients enteral support allows clinical remission (Table 6) and improvement of nutritional status in most cases. In the most severe cases, it may be better to choose elemental diets rather than polymeric ones, because the former seem to induce clinical remission more rapidly. In 
other cases, semi-elemental or polymeric diets may be preferable because they often are cheaper than elemental diets.

\section{CONCLUSIONS}

In conclusion, the management of Crohn's disease patients is incomplete without an awareness of their nutritional status. Early assessment and treatment of malnutrition is essential. In many patients, nutritional therapy will consist of enteral support using tube feeding, because the compliance for elemental diets by mouth is far from good (due to anorexia and to the taste of these diets). TPN must be used only in the most severe cases or when enteral support fails. Further studies are needed to improve the efficacy of enteral support by using more specific diets with better anti-inflammatory and proregenerative properties (eg, diets containing glutamine or omega 3 fatty acids).

\section{REFERENCES}

1. Clark ML. Role of nutrition in inflammatory bowel disease: An overview. Gut 1986;27:72-5.

2. Hunter JD. The dietary management of Crohn's disease. In: Hunter JD, Alun Jones V, eds. Food and the Gut. London: Bailliere Tindall, 1985:221-37.

3. Matuchansky C. Parenteral nutrition in inflammatory bowel disease. Gut 1986;27:81-4.

4. Thornton JR, Emmett PM, Heaton KW. Diet and Crohn's disease: Characteristics of the pre-illness diet. Br Med J 1979;2:762-4.

5. Martini GA, Brander JW. Increased consumption of refined carbohydrates. Klin Wschr 1976;54:367-71.

6. Mayberry JF, Rhodes JF, Newcombe RG. Breakfast and dietary aspects of Crohn's disease. Br Med J 1978:2:1401-3.

7. Harper PH, Lee ECG, Kettlewell MGW, Benneth MK, Jewell DP. Role of the faecal stream in the maintenance of Crohn's colitis. Gut 1985;26:279-84.

8. Alun Jones V, Dickinson RJ, Workman E, et al. Crohn's disease: Maintenance of remission by diet. Lancet 1985;ii:177-80.

9. Voitk AJ, Echave B, Feller JH. Experience of elemental diets in the treatment of inflammatory bowel disease. Is this primary therapy? Arch Surg 1973;107:329-33.
10. Lochs H, Egger-Schodl M, Schuh R, et al. Is tube feeding with elemental diets a primary therapy of Crohn's disease? Klin Wochenschr 1984;62:821-5.

11. Lerebours E, Messing B, Chevalier B, Bories C, Colin R, Bernier JJ. An evaluation of total parenteral nutrition in the management of steroiddependent and steroid-resistant patients with Crohn's disease. J Parent Ent Nutr 1986;10:274-8.

12. Harford FJ Jr, Fazio VW. Total parenteral nutrition as primary therapy for inflammatory diseases of the bowel. Dis Colon Rectum 1978;21:555-7.

13. Dickinson F.J, Ashton MG, Axon ATR, et al. Controlled trial of intravenous hyperalimentation and total bowel rest as an adjunct to the routine therapy of acute colitis. Gastroenterology 1980;79:1 199-204.

14. Greenberg GR, Fleming CR, Jeejeebhoy KN, et al. Controlled trial of bowel rest and nutritional support in the management of Crohn's disease. Gut 1988;29:1309-15.

15. Okada M, Yao T, Yamamoto T, et al. Controlled trial comparing an elemental diet with prednisolone in the treatment of active Crohn's disease. Hepatogastroenterol 1990;37:72-80.

16 O'Morain C, Segal AW, Levi AJ, Valman HB. Elemental diet in acute Crohn's disease. Arch Dis Child 1983;53:44-7.

17. Morin CL, Roulet M, Roy CC, Weber A, Lapointe N. Continuous elemental enteral alimentation in the treatment of children and adolescents with Crohn's disease. J Parent Ent Nutr 1982;6:194-9.

18. Navarro J, Vargus J, Cezard JP, Charritat JL, Polanovski C. Prolonged constant-rate elemental enteral nutrition in Crohn's disease. J Pediatr Gastroenterol Nutr 1982;1:541-56.

19. Alun Jones V. Comparison of total parenteral nutrition and elemental diet in induction of remission of Crohn's disease. Dig Dis Sci 1987;32:100S-7.

20. O'Morain C, Segal AW, Levi AJ. Elemental diet as primary treatment of acute Crohn's disease: A controlled trial. Br Med J 1984;288:1859-62.

21. Saverymuttu S, Hodgson HJF, Chadwick VS. Controlled trial comparing prednisolone with an elemental diet plus nonabsorbable antibiotics in active Crohn's disease. Gut 1985;26:994-8.

22. Seidman EG, Bouthillier L, Weber AM, Roy CC, Morin CL.Elemental diet versus prednisone as primary treatment of Crohn's disease. Gastroenterology 1986;90:1625.

23. Coyle BL, Sladen GE. Whole protein liquid diet in the treatment of acute uncomplicated Crohn's disease. J Hum Nutr Diet 1989;2:25-30.

24. Kerner JD, Polk DB, Hatmer JAT. Improved growth and disease activity following intermittent administration of a defined formula diet in children with Crohn's disease. Trends in inflammatory bowel disease therapy 1992. Quebec City: Falk Symposium, Poster 34.

25. Royall D, Kahan I, Baker JP, et al. Clinical and nutritional outcome of an elemental vs semi-elemental diet in active Crohn's disease, Gastroenterology 1992;102:A576. (Abst)

26. Engelman JL, Murphy GM, Sladen GE. Peptamen. An effective therapy in active ileal Crohn's disease. Trends in inflammatory bowel disease therapy 1992. Quebec City: Falk Symposium, Poster 39.

27. Park RHR, Galloway A, Danesh BJZ, Russell R. Double blind trial comparing elemental and polymeric diet as primary treatment for active Crohn's disease. Gut 1989;30:A1453-4.

28. Raouf AH, Hildrey V, Daniel J, et al. Enteral feeding as sole treatment for Crohn's disease: Controlled trial of whole protein $\mathrm{v}$ amino-acid based feed and a case study of dietary challenge. Gut 1991;32:702-7.

29. Graffer MH, North G, Holdsworth Crohn's disease. Controlled trial of polymeric versus elemental diet in treatment of active Crohn's disease. Lancet 1990;i:816-9.

30. Rigaud D, Cosnes J, Le Quintrec Y, Gendre JP, Mignon M. Controlled trial comparing two types of enteral nutrition in treatment of active Crohn's disease: Elemental versus polymeric diet. Gut 1991;32:1492-7.

31. Teahon K, Bjarnason 1, Pearson $M$, Levi AJ. Ten years' experience with an elemental diet in the management of Crohn's disease. Gut 1990;31:1133-7.

32. Lochs H, Steinhardt HJ, ICaus-Wenz B, Bauer P, Malchow H. Enteral nutrition versus drug treatment for the acute phase of Crohn's disease. Result: of the European Cooperative Crohn's disease study IV. Gastroenterology 1991:101:881-8.

33. Andersson H, Bosaens I, Ellegard L, et al. Comparison of an elemental and two polymeric diets in colectomized patients with or without intestinal resection. Clin Nutr 1984;3:183-9.

34. Ziegler F, Ollivier JM, Cynober L, et al. Efficiency of enteral nitrogen support in surgical patients: Small peptides versus non degraded proteins. Gut 1990;31:1277-83.

35. Bjarnason I, Teahon K, Zanelli G, et al. Elemental diets in the treatment of active Crohn's disease. 
Gastroenterology 1988;94:A37. (Abst)

36. De Leon R, Gonzalez-Huix F, Esteve $\mathrm{M}$, et al. Polymeric enteral nutrition as primary treatment in Crohn's disease. Gastroenterology 1992;102:A614. (Abst)

37. Middleton SJ, Riordan AM, Hunter
JO. Peptide based diet: an alternative to elemental diet in acute Crohn's disease. Gut 1991;32:A5789. (Abst)

38. Ito K, Hiwatashi N, Kinouchi Y, et al. Improvement of abnormal permeability in active Crohn's disease by an elemental diet.
Gastroenterology 1992;102:A641. (Abst)

39. Gorard DA, Hunt JB, Payne-James JJ, et al. Relapse rates in Crohn's disease after initial treatment with elemental diet or prednisolone. Gut 1991;32:A582. (Abst) 


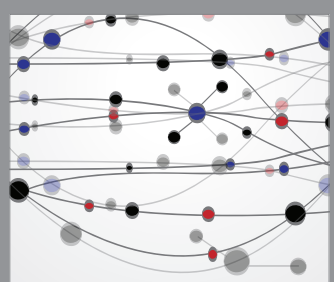

The Scientific World Journal
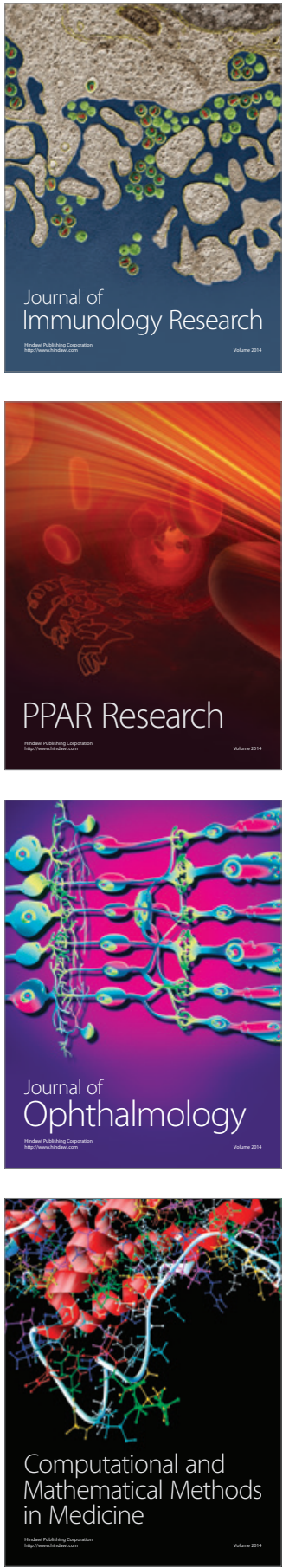

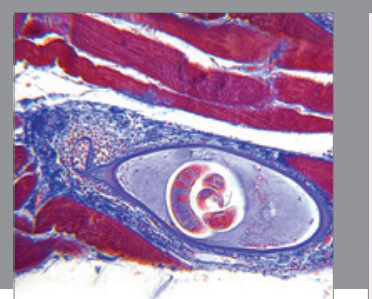

Gastroenterology Research and Practice

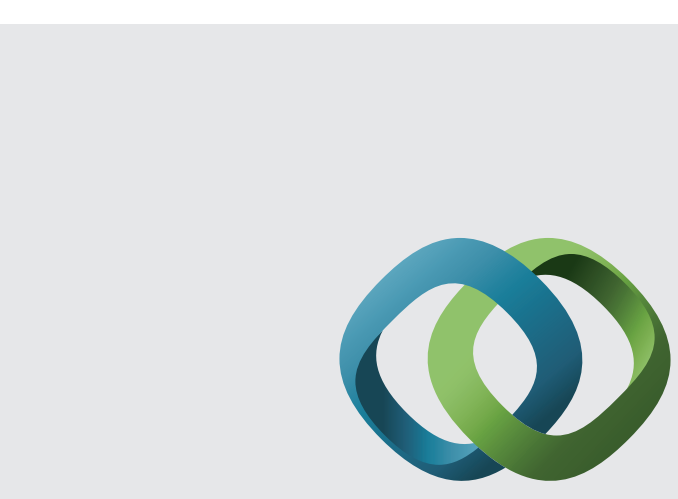

\section{Hindawi}

Submit your manuscripts at

http://www.hindawi.com
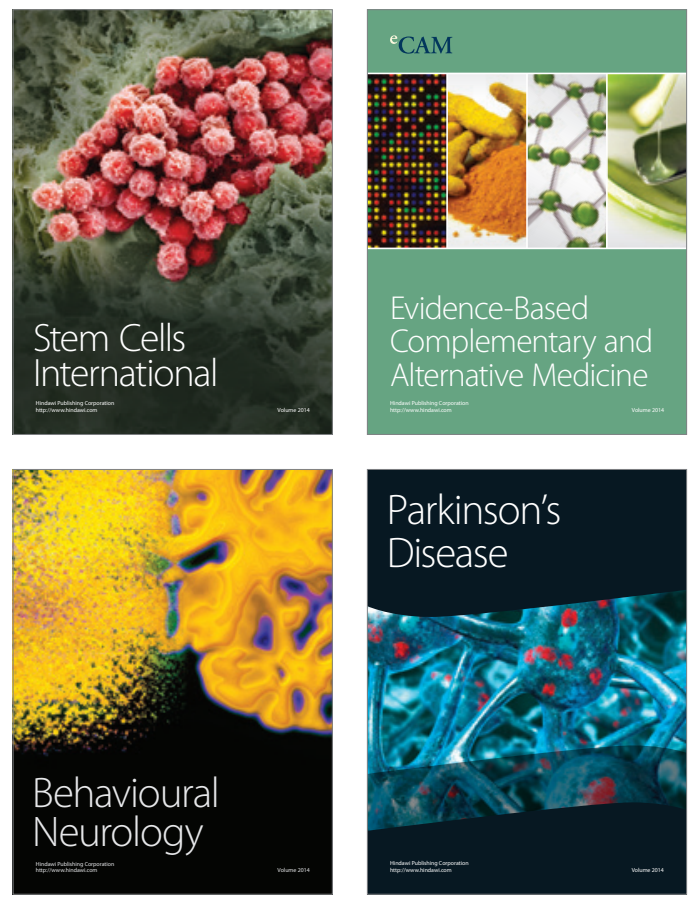
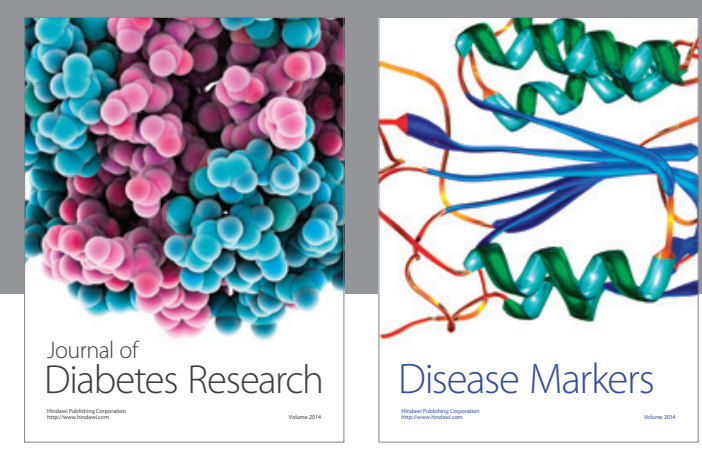

Disease Markers
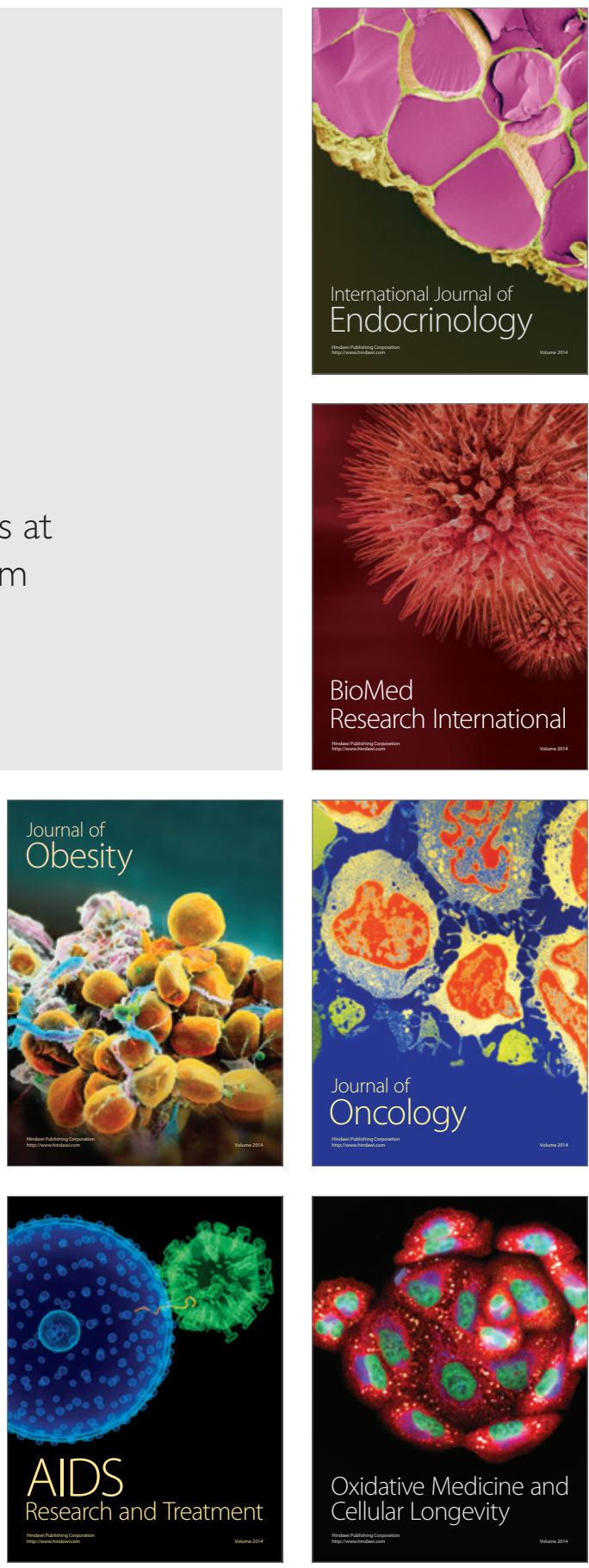